\title{
D-vitamin-anyagcsere és osteoporosis szisztémás sclerosisban
}

\author{
Szamosi Szilvia dr." - Horváth Ágnes dr.* \\ Szekanecz Zoltán dr. - Szű́cs Gabriella dr. \\ Debreceni Egyetem, Általános Orvostudományi Kar, Reumatológiai Tanszék, Debrecen
}

\begin{abstract}
Az elmúlt években egyre több adat jelent meg a D-vitamin immunregulációban betöltött szerepével kapcsolatosan. Feltételezhető, hogy az autoimmun és gyulladásos reumatológiai betegségek patogenezisében és fenntartásában is kiemelkedő jelentősége van az alacsony D-vitamin-szintnek. Számos autoimmun betegségben, így szisztémás sclerosisban (SSc) is gyakori a D-vitamin-deficientia előfordulása, amely asszociációt mutat az - ebben a betegcsoportban tapasztalt - alacsony csontsứrúségértékekkel és az osteoporosis magasabb prevalenciájával. SSc-ben a hagyományos osteoporosis-rizikófaktorok jelenlétén túl egyéb, betegségspecifikus tényezők (bőr- és belszervi érintettség, malabsorptio, szisztémássclerosis-altípus, szerológiai jellegzetességek, gyógyszeres kezelés) is hozzájárulnak a csontásványianyag-tartalom csökkenéséhez. A fenti tényezők komplex interakciói és a klinikai vizsgálatok heterogenitása miatt nehéz azok valódi hatását megítélni a sclerodermás betegek csontsűrűségére, és rendkívül hiányosak az ismereteink a betegek törési rizikójára, illetve osteoporoticus törésekkel összefüggő mortalitására vonatkozóan is. Jelen közleményben áttekintjük a D-vitamin immunmoduláns hatásaival kapcsolatban rendelkezésre álló irodalmi adatokat és összefoglaljuk a szisztémás sclerosisos betegek körében vizsgált D-vitamin-szintre, csontásványianyag-tartalomra, csontanyagcsere-markerek eltéréseire és az osteoporosis előfordulására vonatkozó eredményeket.
\end{abstract}

Orv Hetil. 2017; 158(32): 1252-1258.

Kulcsszavak: D-vitamin, immunreguláció, osteoporosis, törési rizikó, szisztémás sclerosis, fibrosis

\section{Vitamin D metabolism and osteoporosis in systemic sclerosis}

In the past few years more and more data have become available on the important role of vitamin $\mathrm{D}$ in immunological processes and inflammation. The role of vitamin $\mathrm{D}$ deficiency in the pathogenesis as well as in disease progression of different autoimmune and inflammatory conditions is suspected. Vitamin D deficiency is prevalent in several autoimmune diseases, including systemic sclerosis. Hypovitaminosis has been found to be associated with low bone mineral density and higher prevalence of osteoporosis in this group of patients. Determinants of low bone density in SSc are poorly understood. Studies have shown the importance of both traditional osteoporotic as well as diseasespecific factors (extent of skin involvement, presence of internal organ manifestation, malabsorption, systemic sclerosis subtype, serological profile, medication) in the development of low bone mineral density. The relationship between low bone density in systemic sclerosis patients and the above mentioned risk factors may be more complex and the real role of each factor is unclear. Yet very few studies reported clinically relevant low bone mass outcomes such as fracture risk assessment and fracture associated mortality in scleroderma. This review aims to synthesize data about the essential role of vitamin D in immune homeostasis as well as the prevalence of hypovitaminosis, low bone density, changes in bone turnover markers and presence of osteoporosis in scleroderma patients.

Keywords: Vitamin D, immune regulation, osteoporosis, fracture risk, systemic sclerosis, fibrosis

Szamosi Sz, Horváth Á, Szekanecz Z, Szúcs G. [Vitamin D metabolism and osteoporosis in systemic sclerosis]. Orv Hetil. 2017; 158(32): 1252-1258.

(Beérkezett: 2017. május 30.; elfogadva: 2017. június 29.)

*Az első két szerző azonos mértékben vett részt a publikáció megírásában. 


\section{Rövidítések}

$\mathrm{ACA}=$ anticentromer-antitest $\mathrm{ALP}=$ alkalikus foszfatáz; $\mathrm{AO}=$ acroosteolysis; $\mathrm{APC}=$ antigén-prezentáló sejt; $\mathrm{BMD}=($ bone mineral density) csontásványianyag-sưrúség; $\mathrm{BMI}=$ testtömegindex; $\mathrm{CMV}=$ cytomegalovirus; $\mathrm{CRP}=\mathrm{C}$-reaktív protein; CTX $=$ kollagén-C-telopeptid; $\mathrm{DC}=$ dendritikus sejt; dcSSc $=$ diffúz cutan szisztémás sclerosis; DEXA $=$ (dual energy X-ray absorptiometry) kettős energiájú röntgenabszorpciometria; DLCO = szén-monoxid-diffúziós kapacitás; EBV = EpsteinBarr-vírus; FRAX $=($ Fracture Risk Assessment Tool $)$ törésirizikókockázat-becslési kérdőív; FVC = forszírozott vitálkapacitás; $\mathrm{GI}=$ gastrointestinalis; IGF-1 = inzulinszerú növekedési faktor-1; IGFBP = inzulinszerü növekedésifaktor-kötő fehérje; $\mathrm{IgM}=$ immunglobulin $\mathrm{M}$; IL = interleukin; INF- $\gamma=$ interferon-gamma; lcSSc = limitált cutan szisztémás sclerosis; MCTD $=$ kevert kötőszöveti betegség; mRSSc $=$ (modified Rodnan skin score) módosított Rodnan-bőrpontszám; NE = nemzetközi egység; OC = oszteokalcin; OP = osteoporosis; $\mathrm{OPG}=$ oszteoprotegerin; $\mathrm{PAH}=$ pulmonalis artériás hypertonia; $\mathrm{pQCT}=$ perifériás kvantitatív komputertomográfia PTH $=$ parathormon; QUS = kvantitatív csontultrahang; RA = rheumatoid arthritis; SLE = szisztémás lupus erythematosus; Smad $=\mathrm{C}$. elegans protein (SMA) és Drosophila protein (MAD) homológ; sPAP = szisztolés pulmonalis artériás nyomás; sRANKL = soluble receptor activator of nuclear factor kappa-B ligand; SSc $=$ szisztémás sclerosis; STAT4 $=$ signal transducer and activator of transcription 4 ; TGF- $\beta=$ transzformáló növekedési faktor béta; Th-sejt = helper T-sejt; TLR = Toll-like receptor; TNF- $\alpha=$ tumornekrózis-faktor-alfa; VDR $=\mathrm{D}$-vitamin-receptor; $\mathrm{WHO}=($ World Health Organization $)$ Egészségügyi Világszervezet

A szisztémás sclerosis (SSc) egy ritka, krónikus autoimmun-eredetü, kötőszöveti betegség, amelynek éves incidenciája 20/1 millió, prevalenciája 240 eset/1 millió felnőtt lakosra nézve. A betegség jelentkezése 45-65 éves korú nők körében gyakoribb. A kórkép karakterisztikus jellemzője a bőr és bizonyos belső szervek progresszív fibrosisa, de emellett az endothelium diszfunkciója következményeként megjelenő obliteratív vasculopathia és immunaktiváció, autoantitest-termelés is meghatározó szerepű a betegség kialakulásában [1]. A betegségnek a LeRoy-féle klasszifikáció alapján két fó formáját különítjük el, amelyek a bőrérintettség kiterjedtségében és a specifikus antoantitestek jelenlétében is különböznek egymástól. A limitált cutan forma (lcSSc) esetén a betegségre jellemző Raynaud-szindróma kialakulása akár évekkel is megelőzheti az egyéb belszervi tünetek kialakulását, amelyek általában nem olyan súlyos és progresszív jelentkezésúek, mint a diffúz cutan (dcSSc) alcsoportban [2]. A belszervi tünetek közül a gyomorbél rendszer, a tüdő, szív és a vese érintettsége fordul eló leggyakrabban, amelyek közül az interstitialis tüdőbetegség és a pulmonalis artériás hypertonia (PAH) felelősek elsősorban a betegség mortalitásáért [3-5]. A betegség túlélési mutatóit meghatározó súlyos belszervi tünetek mellett a betegek mindennapjait megkeserítő, az életminőségüket befolyásoló mozgásszervi eltérések ta- lán méltatlanul háttérbe szorulnak a tudományos közleményekben. A bőr és az ízület körüli struktúrák, az inak, ízületi tok fibrosisa flexiós kontraktúrák kialakulásához vezet. A fentiek mellett a kézfunkció jelentős romlásához gyulladásos jellegû́, erozív vagy nonerozív arthritis is hozzájárulhat $[6,7]$. A betegség csontanyagcserére gyakorolt hatása nem kellően tisztázott, azonban irodalmi adatok alapján tudjuk, hogy az SSc-s betegek körében a csont ásványianyag-tartalma, a csontsürüség (BMD) és a D-vitamin-szint alacsonyabb, mint a normálpopulációban, így az osteoporosis ( $\mathrm{OP}$ ) előfordulása és a betegek törési rizikója is magasabb $[8,9]$.

OP-ban a csontszövet mikroarchitektúrájának károsodása a csont strukturális integritásának bomlásához vezet, amely a csonttömeg csökkenésével és fokozott törékenységgel jár együtt. Szokták a betegséget „néma járványként” is emlegetni, hiszen az utóbbi években a prevalencia növekszik, azonban sok beteg tünetmentes és nem tud a betegségéről, amennyiben a megfelelő diagnosztikus vizsgálat nem történik meg [10]. A betegek törési rizikójának felmérését illetően az elmúlt időszakban jelentős előrelépés volt az Egészségügyi Világszervezet (WHO) fejlesztése, a Sheffieldi Egyetem Metabolikus Vázmegbetegedések Központjával együttmúködésben kidolgozott Fracture Risk Assessment Tool (FRAX) megalkotása. Ennek fontosságát felismerve a FRAX hazánkban is az Egészségügyi Szakmai Kollégium Reumatológiai Tagozatának szakmai protokollja alapján a diagnosztikus algoritmus részévé vált. A FRAX kiszámítja, hogy hány százalékos valószínűséggel következik be az adott betegnél az elkövetkező 10 év során csípőtáji vagy bármilyen nagyobb OP-s csonttörés, integrálja a páciens klinikai kockázati tényezőkkel kapcsolatos kockázatait. A FRAX szélesebb körü elterjedése közelebb vihet minket az OP-s betegek körében a személyre szabott orvoslás megvalósításához és az egyénre szabott terápia megválasztásához $[11,12]$. A csontsưrúséget és az OP kialakulásának rizikóját számos faktor befolyásolja, többek között az egyén csúcscsonttömege, életkora, az OP-ra, csípőtáji törésre vonatkozó családi anamnézis, a nemi hormonok aktivitása, a szteroidtartalmú szerek krónikus használata, dohányzás, nagymértékű alkoholfogyasztás, illetve bizonyos krónikus társbetegségek jelenléte, amelyek malabsorptiót okoznak vagy befolyásolják a D-vitamin metabolizmusát és krónikus gyulladást tartanak fenn a szervezetben. A BMD-mérés gold standard módszere a kettős energiájú röntgenabszorpciometria (DEXA) -vizsgálat. A DEXA-vizsgálattal mért csípő- és lumbalisgerinc-BMD, illetve az ebból számolt T-scoreértékek alapján a WHO által megalkotott három fő kategóriába soroljuk a pácienseket: egészséges, osteopeniás és OP-s csoportokba [10]. Bár egyéb technikák alkalmazásával nyert eredmények alapján nem tudjuk a konvencionális diagnosztikus klasszifikációt elvégezni, a perifériás kvantitatív komputertomográfia (pQCT) egy olyan vizsgálati metódus, amelynek segítségével szintén jól becsülhető a törési rizikó, és alkalmas a csont strukturális 
változásainak követésére is. A pQCT egy háromdimenziós mérési módszer az alkar és a tibia csontsürüségének mérésére. Egyéb denzitometriás technikákkal szemben a legnagyobb előnye, hogy a corticalis és trabecularis csontot külön képes leképezni, a gerinc esetében a trabecularis csont térfogatának mérését nem befolyásolják a degeneratív meszes csőrképződések. A pQCT-vel valódi csontsürüségmérés történik, az eredményt $\mathrm{g} / \mathrm{cm}^{3}$-ben kapjuk meg, ellentétben a DEXA-vizsgálat során nyert területi denzitással, amelyet $\mathrm{g} / \mathrm{cm}^{2}$-ben adunk meg [13, 14].

A krónikus gyulladásos reumatológiai kórképek és a szisztémás autoimmun betegségek jól ismert osteoporosis-rizikófaktornak számítanak, ezekben a betegpopulációkban a csonttörések kockázata emelkedett. Számos tanulmány leírja a D-vitamin-deficientia és alacsony BMD-értékek magasabb prevalenciáját rheumatoid arthritises (RA), szisztémás lupus erythematosusos (SLE) és kevert kötőszöveti betegségben (MCTD) szenvedő betegek esetében [15-18]. Ezekben a betegségekben a tradicionális osteoporoticus rizikófaktorokon túl a gyulladásnak van kiemelt szerepe, hiszen a gyulladásos citokin miliő kulcsfontosságú a csontátépülés folyamatában. A krónikus gyulladásos állapoton túl az aktív betegség következményeként bekövetkező mozgáskorlátozottság, fizikai inaktivitás és a gyakran alkalmazott szteroidkezelés szintén rizikófaktornak tekinthető ezekben a megbetegedésekben. Az SSc mind patogenezisében, mind a kortikoszteroid terápiás használatát tekintve eltér a fenti gyulladásos reumatológiai kórképektől, mégis úgy túnik, hogy az SSc-s betegek is fokozott OP-rizikóval bírnak. Ehhez szintén hozzájárul az ízületek flexiós kontraktúrája következtében kialakuló és az izomtömegvesztés miatti immobilizáció, a csökkent D-vitamin-szintézis a fibroticus bőrben, a gastrointestinalis (GI) érintettség következtében kialakuló malabsorptio és a vese érintettsége esetén annak elégtelen múködése. A kortikoszteroidok használata SSc-ben közismerten inkább kerülendő, csak egészen kivételes esetekben indokolt, azonban egyéb immunszuppresszív szerek alkalmazása, mint például a cyclophosphamid indirekt módon, korai menopauza indukálása révén hozzájárulhat az OP kialakulásához ebben a betegcsoportban $[19,20]$.

\section{A D-vitamin szerepe az immunregulációban}

A D-vitamin szerepe a kalciummetabolizmus és csonthomeosztázis fenntartásában alapvető és régóta ismert tény, azonban az utóbbi évtizedben felismerték immunmoduláns szerepét is autoimmun és gyulladásos reumatológiai kórképekben. Az immunrendszer sejtjein, a T- és B-lymphocytákon, valamint az antigén-prezentáló sejteken (APC) is megtalálható a D-vitamin receptora (VDR), így ezek a sejtek képesek az aktív D-vitamin szintézisére [21]. Az immunsejtek által termelt D-vitamin ebben a sajátos immunológiai miliőben - köszönhetően a szintéziséért és lebontásáért felelős enzimek eltérő regulációjá- nak - másként viselkedik, mint a szisztémás, keringésben megtalálható hormon. A macrophagok által termelt extrarenalis 1- $\alpha$-hidroxiláz enzim indukciója nem a parathormon $(\mathrm{PTH})$ által, hanem különböző gyulladásos citokinek révén valósul meg, és az immunsejtekben az 1,25-OH-D-vitamin lokális termelését negatív feed-back hatás sem befolyásolja [22, 23]. A D-vitamin autokrin és parakrin módon részt vesz az immuntolerancia fenntartásában, valamint az innate immunrendszer befolyásolásával a fertőzések elleni protektív immunitásban is központi szerepe van. További hatásai az adaptív immunrendszer sejtjeire rendkívül szerteágazóak. Gátolja a B-sejtek proliferációját, differenciációját és egyúttal az immunglobulinok szekrécióját. A Thl citokinek (INF- $\gamma$, IL-1, TNF- $\alpha$ ) termelését szintén gátolja és a Th2 fenotípus irányába tolja el az egyensúlyt. Befolyásolja a T-sejtek érését, a regulatorikus T-sejteket indukálva csökken a proinflammatorikus citokinek (IL-17, IL-21) termelése, míg az antiinflammatorikus IL-4- és IL-10-szintek emelkednek. A dendritikus sejtek (DC) differenciációját és érési folyamatát gátolja, így az éretlen fenotípusú DC-k megőrzésével kiemelkedő szereppel bír az immuntolerancia fenntartásában [24-26]. A D-vitamin direkt antifibroticus hatását állatkísérletekben bizonyították, amelyek során csökkentette a profibroticus TGF- $\beta 1$ expresszióját, valamint a multipotens mesenchymalis sejtek kollagénszintézisét, ugyanakkor elősegítette az ellentétes hatással bíró mátrixmetalloproteinázok expresszióját. A TGF- $\beta 1$ által indukált fibroblastproliferációra, kollagén- és fibronektinexpresszióra és myofibroblastdifferenciációra a D-vitamin szintén gátlóhatással bír [27]. A D-vitamin-receptor-szignalizációnak is fontos szerepe van a kalciumhomeosztázison túl a sejtproliferációban és -differenciációban, valamint az immunmodulációban. Ismeretes, hogy a VDR csökkent expressziója érzékenyíti a normális és SSc-s fibroblastokat a TGF- $\beta$ által indukált fibrosisra. A VDR tehát negatív regulátorként szerepel a TGF- $\beta$ /Smad szignalizációban [28]. A D-vitamin immunrendszerre gyakorolt hatását az 1. táblázat foglalja össze.

\section{A D-vitamin szerepe szisztémás sclerosisban a klinikai vizsgálatok alapján}

Több szerzőcsoport talált alacsony D-vitamin-koncentrációt RA-ban, SLE-ben, MCTD-ben vagy nem differenciált collagenosisban (NDC) szenvedő betegek körében [15-18]. SSc-s kohorszvizsgálatok adatai szintén alacsony D-vitamin-szintekről számolnak be. A hypovitaminosis lehetséges okai között a csökkent napfény-expozíció, az előrehaladott GI-érintettség következtében kialakult malabsorptio, veseérintettség és a bőr fibrosisa valószínú, azonban a fibrosis kiterjedtségének mértéke és a D-vitamin-koncentrációk közötti összefüggés ennél összetettebb. Nehéz arra a kérdésre választ adni, hogy a D-vitamin-deficientia esetlegesen a fibroticus eltérések kiváltó okaként szerepel SSc-s betegekben vagy a bőr 


\section{1. táblázat $\mid 1,25(\mathrm{OH})_{2} \mathrm{D}_{3}$-vitamin hatása az immunrendszerre in vitro}

Gátolja a T-sejt-proliferációt, az interleukin-2 (IL-2), interferon- $\gamma$

(INF- $\gamma$ ) -mRNS és -fehérje expresszióját a T-sejtekben, és a CD8

T-lymphocyták által közvetített citotoxicitást.

A T-sejtek szuppresszor aktivitását elősegítik.

Gátolja a T-helper-1 (Thl) -sejtek által indukált citokinek, kiváltképp az INF- $\gamma$ expresszióját, elősegíti a Th2-választ.

Az antigén-prezentáló dendritikus sejtekre (DC) hatva az IL-12-

szintézist gátolja, amelynek fontos szerepe van a Thl-sejtes válaszadásban.

Az IL-6- és IL-23-expresszió gátlása révén indirekt módon gátolja a Th17-választ

Az IL-10 termelését elősegíti.

A regulatorikus T-sejtek (Treg) differenciációjában szerepet játszik.

A B-sejt-proliferációt, plazmasejtek differenciációját és Ig szekrécióját gátolja.

Az MHC-II molekulák és a CD40, CD80 és CD86 expressziójának gátlása révén az innate immunitásban fontos szerepet betöltő DC-k differenciációját, érését is befolyásolja.

In vitro stimulálja a humán monocyták proliferációját, az IL-1, valamint a monocyták és macrophagok által termelt antimikrobiális peptid, a cathelicidin termelését.

Állatkísérletekben a TGF- $\beta 1$, kollagén-I és kollagén-III expresszióját gátolva direkt antifibrotikus hatással bír.

előrehaladott fibrosisának a következménye [29]. Allanore és mtsai az SSc-s betegek körében a Toll-like receptor (TLR) szignalizációjában fontos szerepet betöltő interferon regulatorikus faktor 5 (IRF5) különböző variánsait írták le, amelyek - csakúgy, mint SLE-s betegekben - összefüggésben lehetnek a betegség kialakulásával. Emellett a STAT4 rs7574865 genetikai variánsa szintén fogékonyságot jelez az SSc kialakulására, amelynek hátterében a STAT4 IL-12 és IL-23 receptor szignalizációjában és a Thl- és Thl7-irányú polarizációban betöltött szerepe állhat [30]. Ha ezeket az adatokat öszszevetjük a D-vitamin fentebb leírt in vitro bizonyítékokon alapuló adaptív immunsejtekre gyakorolt inhibitoros hatásaival, akkor joggal feltételezhetjük, hogy a D-vitaminnak szerepe van az SSc patogenezisében. SSc-s betegek dermalis fibroblastjaiban és sclerodermás egérmodellekben is csökkent VDR-expresszió látható, a fibroblastok TGF-ß-ra szenzibilizálódnak. Így a betegség patogenezisében a megváltozott VDR-szignalizációnak is szerepet tulajdonítanak a hiperaktív TGF- $\beta$-jelátvitel, következményes aberráns fibroblast-aktiváció révén [28]. A VDR-polimorfizmus esetenként összefüggésbe hozható bizonyos vírusok (például CMV, EBV, parvovírus B19) vagy baktériumok (például $H$. pylori) jelenlétével, amelyek a betegség kezdeti szakaszára jellemző endothelsérülés elindítói lehetnek [29]. Izraeli szerzők 87\%-ban D-vitamin-ellenes antitestek jelenlétét találták SSc-s betegekben, az anti-1,25-OH-D-IgM-antitest-titer értéke a vizsgált betegekben szignifikánsan magasabb volt, mint az egészséges kontrollokban. Az antitestek pa- togenetikai, diagnosztikai vagy prognosztikai szerepe azonban kérdéses, további vizsgálatokat igényel [31].

A klinikai vizsgálatok eredményei nem minden esetben hoztak azonos eredményeket a D-hypovitaminosis előfordulására vonatkozóan SSc-ben. A sclerodermás belszervi tünetekkel vagy szerológiai jellemzőkkel való korreláció tekintetében is különbségek adódtak az egyes kohorszokban. Egy retrospektív vizsgálatban az SSc-s betegek 46\%-ában találtak D-hypovitaminosist (<12 ng/ $\mathrm{ml}$ ), és ebben a csoportban $22 \%$-ban volt magasabb a PTH-szint. Az alacsony D-vitamin-szinttel rendelkezó betegek felénél acroosteolysis (AO) volt jelen, azonban sem a betegség súlyosságával, sem a fennállási idejével nem mutatott korrelációt a $\mathrm{D}$-vitamin vagy a PTH szintje. Az AO kialakulásában a vascularis sérülésen túl a szekunder hyperparathyreosisnak, fokozott csontturnovernek is szerepe lehet [32]. Két egymástól független, egy észak francia és egy dél olasz kohorsz 156 SSc-s beteg adatait vizsgálta együttesen. $131 / 156$ beteg (84\%) esetében D-vitamin-insufficientia $(25-\mathrm{OH}$-D-vitamin-szint $<75 \mathrm{nmol} / \mathrm{l}$ ), míg 44/156 betegnél (28\%) D-vitamindeficientia (25-OH-D-vitamin-szint $<50 \mathrm{nmol} / \mathrm{l})$ volt megfigyelhető. Az alacsony D-vitamin-szintek nem voltak összefüggésbe hozhatók a malabsorptióval társuló laboratóriumi eltérésekkel (hemoglobin, ferritin, albumin, $B_{12}$-vitamin, folsav) vagy az antinukleáris antitestek szintjével. Szignifikáns negatív korrelációt találtak az európai betegségaktivitási pontszám értéke és az akutfázisfehérjék szintje, valamint az alacsony D-vitamin-szintek között. A szisztolés pulmonalis artériás nyomás (sPAP) és a pulmonalis fibrosis gyakrabban társult D-vitamindeficientiával [33]. Arnson és mtsai inverz korrelációt figyeltek meg a D-vitamin-szintek és módosított Rodnanbőrpontszám (mRSSc) tekintetében, míg egy másik német kohorszban nem találtak ilyen jellegü összefüggést [34]. Egy 65 SSc-s beteget felölelő olasz tanulmányban Caramaschi és mtsai szintén magas arányban írták le D-vitamin-insufficientia vagy -deficientia jelenlétét (66 és 29\%), a betegek átlagos D-vitamin-szintje 15,8 $\pm 9,1 \mathrm{ng} / \mathrm{ml}$ volt. A D-hypovitaminosis gyakrabban társult hosszabb betegségfennállási idővel, alacsony szénmonoxid-diffúziós kapacitás (DLCO) -értékekkel, becsült magasabb PAP- és CRP-értékekkel, gyorsult szedimentációval. Érdekes módon a malabsorptio és a D-hypovitaminosis kialakulása között ez a szerzőcsoport sem talált összefüggést [35]. Egy másik olasz munkacsoport, Belloli és mtsai ugyanakkor nem találtak szignifikáns különbséget a D-vitamin-hiány előfordulásában a $43 \mathrm{SSc}$-s beteg és az osteoarthritisben szenvedő kontrollcsoport között [36]. Egyetlen brazil tanulmány vizsgált juvenilis sclerodermás betegeket, akiknél szignifikánsan magasabb volt a D-vitamin-insufficientia prevalenciája, mint a korban és nemben illesztett kontrollcsoportban (100 vs. $40 \%$ ), és ez pozitív korrelációt mutatott a femoralis látszólagos csontásványianyag-sűrüséggel (BMD) [37]. Fontos kérdés a D-vitamin-alapú terápiák használata SSc-ben, amelynek lehetőségei a D- 
vitamin-pótlás és a D-vitamin-analógok használata. Az előbbi a legkézenfekvőbb és olcsóbb lehetőség, azonban több szerzőcsoport is arra a következtetésre jutott, hogy a szokványos napi $800 \mathrm{NE}$ kolekalciferolpótlással nem lehet teljesen kiküszöbölni és megelőzni a D-vitamin-hiányállapotot. A D-vitamin szintetikus analóg kalcipotrién százszoros hatékonysággal rendelkezik az in vivo kalciumabsorptiót és -mobilizációt tekintve a kalcitriolhoz képest. Immunmoduláns hatásuk a TGF- $\beta$ és egyéb citokinek szignalizációjának és aktivált T-sejtek funkciójának gátlásán keresztül érvényesül, azonban használatukra vonatkozóan nagyon kevés humán, klinikai eredménnyel rendelkezünk. Topikus használatuk során az SSc-s betegek bőrén az erythema, teleangiectasiák, pigmentációs eltérések és az induráció mértéke is szignifikánsan csökkent három hónapos kezelés után, de a valódi hatékonyság megerősítésére kettős vak, placebokontrollált vizsgálat nem történt $[24,38]$.

\section{Egyéb csontanyagcsere-markerek vizsgálata SSc-ben klinikai vizsgálatok alapján}

A csontturnover markereinek vizsgálatára SSc-ben több eset-kontroll tanulmányban került sor. Dovio és mtsai az oszteokalcin (OC), alkalikus foszfatáz (ALP), I-es típusú kollagén-C-telopeptid (CTX), oszteoprotegerin (OPG) szolúbilis RANKL (sRANKL) szintjeit és az sRANKL/ OPG arányt vizsgálták. SSc-s betegekben az utóbbi kettő szintje emelkedett volt, amely negatív korrelációt mutatott a BMD-értékekkel [39]. A magas sRANKL-szint potenciális célpontként szerepelhet, amennyiben ineffektivitás vagy gastrointestinalis intolerancia miatt a biszfoszfonátterápia helyett denosumabterápiát alkalmazunk [9]. Az inzulinszerü növekedési faktor-1 (IGF-1) és az IGF-kötő fehérje (IGFBP) csontanyagcserében betöltött szerepéről, BMD-re gyakorolt hatásáról is egyre többet tudunk. A csontban termelődő IGF-1-nek fontos szerepe van a csúcscsonttömeg kialakulásában, illetve csökkenő szintje a csont corticalis állományában bekövetkező csontvesztés révén szerepet játszik az OP patogenezisében [40]. Japán szerzők emelkedett IGF- és IGFBP3-szinteket találtak SSc-s betegeknél a kontrollcsoporthoz képest, az értékek korreláltak a bőrérintettség kiterjedésével és a pulmonalis fibrosis jelenlétével. Úgy tûnik tehát, hogy a betegség patogenezisében és a fibrosis indukciójában is fontos szereppel bírnak [41]. A CTX szintjét SSc-ben nemcsak a csontanyagcsere befolyásolja, miután a tüdőben és a bőrben is aktív kollagénszintézis és -lebontás zajlik. Ennek megfelelően a bőrérintettség kiterjedtsége és a forszírozott vitálkapacitás (FVC) csökkent értéke mellett is találkozhatunk emelkedett CTXértékekkel [42]. Több vizsgálatban találtak magasabb PTH-szinteket SSc-s betegekben a kontrollokhoz képest, ami inverz korrelációt mutatott a D-vitamin-szintekkel. Olasz szerzők a fokozott osteoclast-aktivitást jelző magasabb deoxipiridinolin és a fokozott osteoblastaktivitást mutató oszteokalcinszinteket egyaránt maga- sabbnak találták sclerodermában. Feltételezésük szerint e betegcsoportban az OP és csonttörések magasabb rizikójában szerepet játszik az akcelerált csontanyagcsere is [43].

\section{A csontsűrüségértékek és osteoporosis SSc-ben klinikai vizsgálatok alapján}

Az osteoporosisrizikó megítélése SSc-s betegekben szintén ellentmondásos a relatíve kevés rendelkezésre álló evidencia és a vizsgálatok heterogenitása miatt. Egy 2013-ban megjelent szisztémás áttekintő vizsgálat összegyüjtött adatai alapján az OP prevalenciája 3 és $51,1 \%$ között volt SSc-ben [9]. Olasz szerzők a vertebralis törések és az OP prevalenciáját is magasabbnak találták posztmenopauzális SSc-s betegekben, mint az egészséges kontrollokban (22 vs. 8\%), annak ellenére, hogy a két csoport OP-ra vonatkozó rizikófaktorai (életkor, posztmenopauza kezdete, BMI, családi törési anamnézis, dohányzás, alkoholfogyasztás) megegyeztek [43]. Több vizsgálatban találtak SSc-ben alacsony BMD-értékeket, ahol kontrollcsoportként egészségesek, osteoarthrosisos, RA-s vagy egyéb szisztémás autoimmun betegségben szenvedő betegek vettek részt. Egy marokkói szerzőcsoport $60 \mathrm{SSc}$-s beteg esetében alacsonyabb BMD-értékeket és az OP magasabb arányú előfordulását találták egészséges kontrollokhoz képest, ami összefüggésbe volt hozható a hosszabb betegségfennállási idővel és a korai menopauzával. A csontvesztés mértéke szintén asszociációt mutatott az ízületi érintettség súlyosságával, az erozív kézkisízületi eltérések jelenlétével, valamint a malabsorptióval [44]. Az alacsonyabb BMD-érték egyéb belszervi tünetek jelenlétével a legtöbb vizsgálatban nem mutatott korrelációt. Avouac és mtsai az OP és a törések prevalenciáját hasonlóan magas arányúnak találta $\mathrm{SSc}$ ben (30 és 35\%), mint RA-s betegeknél (32\% és 33\%), de szignifikáns különbség volt az egészséges kontrollokhoz képest (11\% és 10\%). A kumulatív kortikoszteroiddózis csak az RA-s csoportban, a betegek idősebb életkora és a D-vitamin-hiány mind SSc-ben, mind RA-ban az osteoporoticus törések és alacsony BMD független rizikófaktorának bizonyultak. A CRP-érték, menopauzában eltöltött időtartam vagy az SSc szubtípusa nem jelentett magasabb rizikót, azonban az RA-s betegekben a biológiai terápia védőfaktornak bizonyult a törésekkel szemben. Érdemes megemlíteni, hogy a sclerodermás és RA-s OP-s törést szenvedett betegeknek csak 52\%-ában diagnosztizáltak a BMD-értékek alapján osteoporosist, holott ezeknek a betegeknek a törési rizikója biztosan magasabb [15]. A csont-mikroarchitektúra károsodásának felmérésére ebben a betegpopulációban tehát a hagyományos DEXA-vizsgálaton túl biztosan szükség van újabb technikák alkalmazására, amelyek jobban karakterizálják a trabecularis csont struktúrájának eltéréseit és a törési rizikót. Frediani és mtsai nem csupán alacsony BMD-értékeket, hanem kvantitatív csontultrahang (QUS) segítségével a csont struktúrájának minőségbeli 
Tradicionális osteoporosis-rizikófaktorok

(életkor, nem, korai menopauza, családi anamnézis, kortikoszteroidterápia, dohányzás, etnikum, fizikai aktivitás, korábbi csonttörés)

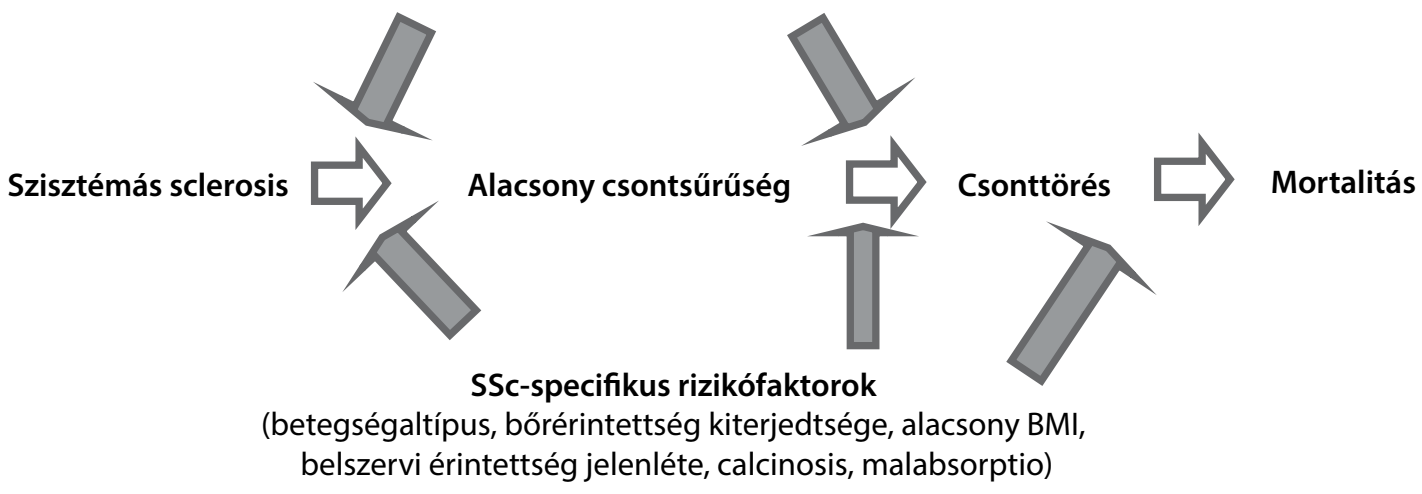

eltéréseit is leírják SSc-ben. A kvalitatív eltérések nem voltak összefüggésbe hozhatók a betegség fennállási idejével, gyulladásos markerekkel vagy egyéb szerológiai eltérésekkel, azonban a dcSSc-alcsoportban a bőrérintettség és a belszervi tünetek kiterjedtségével igen [45]. Francia szerzők a kvalitatív eltérések detektálására SSc-s betegekben a DEXA-vizsgálaton túl magas felbontású pQCT-t használtak. A tibia és radius volumetriás BMDértékei szignifikánsan alacsonyabbak voltak az SSc-s csoportban az egészséges kontrollokhoz képest, ami összefüggést mutatott az alacsony BMI-vel, a betegek idősebb életkorával, az anticentromer-antitest (ACA) és a digitális fekélyek jelenlétével [46].

\section{Következtetés}

$\mathrm{Az}$ irodalmi adatok alapján egyértelmúen megállapítható, hogy az SSc-s betegek gyakrabban szenvednek D-vitamin-hiányban, magasabb a törési rizikójuk és gyakoribb az alacsony BMD-értékek előfordulása e betegcsoportban. Ezt a helyzetet tovább súlyosbítja az, ha az osteoporosis egyéb hagyományos rizikófaktorai jelen vannak. A betegségre jellemző, SSc-specifikus rizikófaktorok szerepe nem egyértelmű, az asszociáció az SSc altípusa, bőrérintettség kiterjedtsége, alacsony BMI, belszervi érintettség, calcinosis és malabsorptio jelenléte, valamint az alacsony BMD-értékek között nem egyértelmúen bizonyított, az ok-okozati kapcsolat sokszor nehezen megmagyarázható. A sokféle faktor komplex szerepe és interakciói miatt valószínűtlen, hogy ezek mindegyike független rizikófaktorként szerepeljen az alacsony csontsưrűség kialakulásában, de az eddigi eredmények alapján mindenképpen hozzájárulnak a folyamathoz (1. ábra). A vizsgálatok klinikai és metodikai heterogenitása, illetve a kis esetszám tovább nehezíti a megfelelő következtetések levonását [9]. A korábbi felmérések nagy hiányossága, hogy az alacsony BMD-értékkel összefüggésbe hozható klinikailag releváns adatok, mint a törések előfordulása és a töréssel összefüggő mortalitás nagyon kis számban állnak rendelkezésre, illetve a jövőben tervezett vizsgálatokba már a 10 éves törési rizikó becslését is be kellene építeni.

Anyagi támogatás: A közlemény megírása anyagi támogatásban nem részesült.

Szerzői munkamegosztás: A közlemény megírásában minden szerző részt vett. A cikk végleges változatát valamennyi szerző elolvasta és jóváhagyta.

Érdekeltségek: A szerzőknek nincsenek érdekeltségeik.

\section{Irodalom}

[1] Gabrielli A, Avvedimento EV, Krieg T. Scleroderma. N Engl J Med. 2009; 360: 1989-2003.

[2] LeRoy EC, Medsger TA. Criteria for the classification of early systemic sclerosis. J Rheumatol. 2001; 28: 1573-1576.

[3] Hissaria P, Lester S, Hakendorf P, et al. Survival in scleroderma: results from the population-based South Australian Register. Intern Med J. 2011; 41: 381-390.

[4] Simeón CP, Armadans L, Fonollosa V, et al. Mortality and prognostic factors in Spanish patients with systemic sclerosis. Rheumatology 2003; 42: 71-75.

[5] Al-Dhaher FF, Pope JE, Ouimet JM. Determinants of morbidity and mortality of systemic sclerosis in Canada. Semin Arthritis Rheum. 2010; 39: 269-277.

[6] Hudson M, Thombs BD, Steele R, et al. Health-related quality of life in systemic sclerosis: a systematic review. Arthritis Rheum. 2009; 61: 1112-1120.

[7] Sandqvist G, Eklund M, Akesson A, et al. Daily activities and hand function in women with scleroderma. Scand J Rheumatol. 2004; 33: 102-107.

[8] Loucks J, Pope JE. Osteoporosis in scleroderma. Semin Arthritis Rheum. 2005; 34: 678-682.

[9] Omair MA, Pagnoux C, McDonald-Blumer H, et al. Low bone density in systemic sclerosis. A systematic review. J Rheumatol. 2013; 40: 1881-1890.

[10] Rachner TD, Khosla S, Hofbauer LC, et al. Osteoporosis: now and the future. Lancet 2011; 377: 1276-1287.

[11] Unnanuntana A, Gladnick BP, Donnelly E, et al. The assessment of fracture risk. J Bone Joint Surg Am. 2010; 92: 743-753. 
[12] Brewer L, Williams D, Moore A. Current and future treatment options in osteoporosis. Eur J Clin Pharmacol. 2011; 67: 321331.

[13] Engelke K, Adams JE, Armbrecht G, et al. Clinical use of quantitative computed tomography and peripheral quantitative computed tomography in the management of osteoporosis in adults: the 2007 ISCD official positions. J Clin Densitom. 2008; 11: 123-162.

[14] Boutroy S, Bouxsein ML, Munoz F, et al. In vivo assessment of trabecular bone microarchitecture by high-resolution peripheral quantitative computed tomography. J Clin Endocrinol Metab. 2005; 90: 6508-6515.

[15] Avouac J, Koumakis E, Toth E, et al. Increased risk of osteoporosis and fracture in women with systemic sclerosis: a comparative study with rheumatoid arthritis. Arthritis Care Res. 2012; 64: 1871-1878

[16] Sun YN, Feng XY, He L, et al. Prevalence and possible risk factors of low bone mineral density in untreated female patients with systemic lupus erythematosus. Biomed Res Int. 2015; 2015: 510514 .

[17] Amital H, Szekanecz Z, Szűcs G, et al. Serum concentrations of $25-\mathrm{OH}$ vitamin $\mathrm{D}$ in patients with systemic lupus erhythematosus (SLE) are inversely related to disease activity: is it time to routinely supplement patients with SLE with vitamin D? Ann Rheum Dis. 2010; 69: 1155-1157.

[18] Zold E, Szodoray P, Gaal J, et al. Vitamin D deficiency in undifferentiated connective tissue disease. Arthritis Res Ther. 2008; 10: R123.

[19] Frediani B, Baldi F, Falsetti P, et al. Bone mineral density in patients with systemic sclerosis. Ann Rheum Dis. 2004; 63: 326327

[20] Sampaio-Barros PD, Costa-Paiva L, Filardi S, et al. Prognostic factors of low bone mineral density in systemic sclerosis. Clin Exp Rheumatol. 2005; 23: 180-184.

[21] Bikle D. Nonclassic action of vitamin D. J Clin Endocrinol Metab. 2009; 94: 26-34

[22] Wu S, Ren S, Nguyen L, et al. Splice variants of the CYP27bl gene and the regulation of 1,25-dihydroxyvitamin $\mathrm{D}_{3}$ production. Endocrinology 2007; 148: 3410-3418.

[23] van Etten E, Stoffels K, Gysemans C, et al. Regulation of vitamin D homeostasis: implications for the immune system. Nutr Rev. 2008; 66(10 Suppl 2): S125-S134.

[24] Vacca A, Cormier C, Methieu A, et al. Vitamin D levels and potencial impact in systemic sclerosis. Clin Exp Rheumatol. 2011; 29: 1024-1031.

[25] Daniel C, Sartory NA, Zahn N, et al. Immune modulatory treatment of trinitrobenzene sulfonic acid colitis with calcitriol is associated with a change of a Thelper (Th) $1 /$ Th17 to a Th2 and regulatory T cell profile. J Pharmacol Exp Ther. 2008; 324: 23-33.

[26] Orbach H, Zandman-Goddard G, Amital H, et al. Novel biomarkers in autoimmune diseases: prolactin, ferritin, vitamin $\mathrm{D}$, and TPA levels in autoimmune diseases. Ann NY Acad Sci. 2007; 1109: 385-400.

[27] Yang CY, Leung PS, Adamopoulos ME, et al. The implication of vitamin D and autoimmunity: a comprehensive review. Clin Rev Allergy Immunol. 2013; 45: 217-226.

[28] Zerr P, Vollath S, Palumbo-Zerr K, et al. Vitamin D receptor regulates TGF- $\beta$ signalling in systemic sclerosis. Ann Rheum Dis. 2015; 74: e20.
[29] Bivona G, Agnello L, Pivetti A, et al. Association between hypovitaminosis D and systemic sclerosis: True or fake? Clin Chim Acta 2016; 458: 115-119.

[30] Allanore Y, Wipff J, Kahan A, et al. Genetic basis for systemic sclerosis. Joint Bone Spine 2007; 74: 577-583.

[31] Carmel NN, Rotman-Pikielny P, Lavrov A, et al. Vitamin D antibodies in systemic sclerosis patients: findings and clinical correlations. Isr Med Assoc J. 2015; 17: 80-84.

[32] Braun-Moscovici Y, Furst DE, Markovits D, et al.: Vitamin D, parathyroid hormone and acroosteolysis in systemic sclerosis. J Rheumatol. 2008; 35: 2201-2205.

[33] Vacca A, Cormier C, Piras M, et al. Vitamin D deficiency and insufficiency in 2 independent cohorts of patients with systemic sclerosis. J Rheumatol. 2009; 36: 1924-1929.

[34] Arnson Y, Amital H, Agmon-Levin N, et al. Serum 25-OH vitamin $\mathrm{D}$ concentrations are linked with various clinical aspects in patients with systemic sclerosis: a retrospective cohort study and review of literature. Autoimmun Rev. 2011; 10: 490-494.

[35] Caramaschi P, Dalla Gassa A, Ruzzenente O, et al. Very low levels of vitamin D in systemic sclerosis patients. Clin Rheumatol. 2010; 29: 1419-1425.

[36] Belloli L, Ughi N, Marasini B. Vitamin D in systemic sclerosis. Clin Rheumatol. 2011; 30: 145-146.

[37] Shinjo SK, Bonfá E, de Falco Caparbo V, et al. Low bone mass in juvenile onset sclerosis systemic: the possible role for 25-hydroxyvitamin D insufficiency. Rheumatol Int. 2011; 31: 1075-1080.

[38] Bottomley WW, Jutley J, Wood EJ, et al. The effect of calcipotriol on lesional fibrosblasts from patients with active morphoea. Acta Derm Venereol. 1995; 75: 364-366.

[39] Dovio A, Data V, Carignola R, et al. Circulating osteoprotegerin and soluble RANK ligand in systemic sclerosis. J Rheumatol. 2008; 35: 2206-2213

[40] Zofková I. Pathophysiological and clinical importance of insulinlike growth factor-1 with respect to bone metabolism. Physiol Res. 2003; 52: 657-679.

[41] Hamaguchi Y, Fujimoto M, Matsushita T, et al. Elevated serum insulin-like growth factor (IGF-1) and IGF binding protein-3 levels in patients with systemic sclerosis: possible role in the development of fibrosis. J Rheumatol. 2008; 35: 2363-2371.

[42] Allanore Y, Borderie D, Lemaréchal H, et al. Correlation of serum collagen I carboxyterminal telopeptide concentrations with cutaneous and pulmonary involvement in systemic sclerosis. J Rheumatol. 2003, 30; 68-73.

[43] Atteritano M, Sorbara S, Bagnato G, et al. Bone mineral density, bone turnover markers and fractures in patients with systemic sclerosis: a case control study. PLoS ONE 2013; 8: e66991.

[44] Ibn Yacoub Y, Amine B, Laatiris A, et al. Bone density in Moroccan women with systemic scleroderma and its relationships with disease-related parameters and vitamin D status. Rheumatol Int. 2012; 32: 3143-3148

[45] Frediani B, Baldi F, Falsetti P, et al. Clinical determinants of bone mass and bone ultrasonometry in patients with systemic sclerosis. Clin Exp Rheumatol. 2004; 22: 313-318.

[46] Marot M, Veléry A, Esteve E, et al. Prevalence and predictive factors of osteoporosis in systemic sclerosis patients: a case-control study. Oncotarget 2015; 6: 14865-14873.

(Szamosi Szilvia dr., Debrecen, Nagyerdei krt. 98., 4032 e-mail: szamosi.szilvi@gmail.com) 